\title{
Comparison of Transradial Versus Transfemoral Approach for Coronary Angiography and Percutaneous Coronary Intervention
}

\author{
Azraai M. ${ }^{1,3}$, Ajani AE..$^{1,2,3 *}$ \\ ${ }^{1}$ Royal Melbourne Hospital, Melbourne \\ ${ }^{2}$ NHMRC Centre of Clinical Research Excellence in Therapeutics, Department of Epidemiology and Preventive \\ Medicine, Monash University, Melbourne \\ ${ }^{3}$ University of Melbourne, Melbourne, Victoria, Australia
}

\begin{abstract}
Historically, transfemoral approach (TFA) was the main access site for percutaneous coronary procedure. Over the past decade, transradial approach (TRA) has been gaining popularity over (TFA). With frequent use of TRA, we have recognized the advantage of TRA over TFA. Multiple trials have been conducted to investigate TRAs' benefits and risk. We have performed a literature search on TRA vs TFA, on the advantages and disadvantages of both approaches. A total of 140 citations were identified but only 38 filled our eligibility criteria.

In this review, we found that TRA is associated with reduction of access site complication, time to ambulation and cardiac related death. However, lack of training and hesitancy of older interventionalist to switch approach is an impediment to the increased use of TRA. While the transfemoral approach has a higher access site complication rate, it is still integral as an access option.
\end{abstract}

Keywords: Transradial, Transfemoral, Percutanous coronary intervention.

\section{Introduction}

Percutaneous coronary intervention has revolutionized the field of cardiology and has become the cornerstone of management of ischaemic heart disease $(1,2)$. Historically, coronary angiography and intervention has been commonly performed via the common femoral artery (3). However, this procedure is associated with bleeding complications, exacerbated by advances in aggressive periprocedural pharmacotherapy (4). New technological advancements such as reduction in size of interventional devices and the introduction of vascular closure devices have reduced the incidence of major bleeding, but major complications still occur (5-8).

Campeau was the first to introduce coronary angiography via the transradial approach (through the forearm) in 1989 (9). Several early studies reported a significant reduction in vascular complication with transradial approach compared with the transfemoral approach (10-13). These studies raised interest in the transradial access site as a viable and attractive alternative to femoral access $(14,15)$.

\section{Materials and Methods}

Relevant studies were identified by searching the following data sources - Medline via Ovid, Embase, Cochrane Library and using the 'related citation' search tool in PubMed. Reference lists from identified studies were also scanned to identify any other relevant studies.

\section{The following inclusion criteria were used:}

(i) studies comparing patients undergoing transfemoral or transradial approach (ii) comparison of outcome, benefit and risk between the two approaches. Meta analyses and systemic review were also included in this review. Duplicate publications were excluded.

The search strategy identified 155 citations. 25 studies were duplicates and after screening of titles and abstracts, a further 83 studies were included. Of the 83 studies selected, 47 fulfilled out eligibility criteria and are included in this systematic review.

Corresponding Author: Andrew. E. Ajani, Department of Cardiology, Royal Melbourne Hospital, Grattan Street, Parkville, 3050, Australia Received date: May 14, 2019; Accepted date: May 21, 2019; Published date: May 22, 2019.

DOI: https://doi.org/10.31546/JCCCVT.1003 


\section{Results and Discussion}

The Radial Versus Femoral Access for Coronary Angioplasty and Intervention in Patients with Acute Coronary Syndromes (RIVAL) study set out to determine whether radial access was superior to femoral access. This study demonstrated that transradial procedure were associated with a $60 \%$ reduction in vascular complications (especially in women) when compared with femoral approach, but showed no significant difference in rates of death, MI, stroke, or major bleed $(16,17)$.

Minimizing Adverse Haemorrhagic Events by Transradial Access Site and Systemic Implementation of AngioX (MATRIX) trial compared transradial versus transfemoral approach in patients with ACS. The study showed no reduction in rates of MI, stroke, or major bleeding at 30 days, however a $63 \%$ reduction of vascular-access complications was seen in the transradial group (18).

Several early studies reported a reduction in mortality rates in patients undergoing transradial access for STEMI (1921). An example is the Radial Versus Femoral Randomized Investigation in ST Elevation Acute Coronary Syndrome (RIFLE-STEACS) trial. The study not only found a $47 \%$ reduction in the rate of access-site related bleeding complications, but also a reduction in the rate of cardiac death and hospital stay with transradial procedure (22). The benefit in reduction of MACE has been proven even in with ACS who undergo transradial access (23)

Further advantages of transradial approach include immediate ambulation, reduced post-procedure nursing care, reduced hospital stay and related costs, and an overwhelming patient preference for transradial angiography (24-28) . Opponents of radial access have cited an associated learning curve (29) with adopting the transradial approach resulting in longer procedural time and increased radiation exposure $(30,31)$. Higher-volume radial operators however exhibit shorter procedural and fluoroscopy times as their procedural experience increases (32). Multivariate analysis found the highest radial volume centres and operators had the lowest radiation exposure (33).

An Analysis of Safety Outcomes for Radial Versus Femoral Access for Percutaneous Coronary Intervention from a large clinical registry was performed. This study involves the use of a multi-site registry of 58,862 percutaneous coronary intervention (PCI) procedures in a national healthcare system, the largest clinical registry of treatment practices comparing radial and femoral access outcome. The primary end points were major bleeding and radiation exposure (34). The results showed that femoral access accounted for $94.7 \%$ and radial access $5.3 \%$ of the procedures. There were fewer bleeding events in the radial group (0.9\%) than those in the femoral group (2.2\%).Among patients receiving anticoagulants, the femoral bleeding rate was $4.3 \%$ compared with radial bleeding rate of $0.7 \%$. For patients receiving bivalirudin, bleeding occurred in 337 patients (1.6\%). Radiation exposure in radial cases was significant in cases involving prior coronary artery bypass graft history and non-ST-elevation myocardial infarction. The fluoroscopy time overall was longer among radial cases (19.9min) compared to femoral access (15.7 $\mathrm{min})(34)$. The limitation of this study is the difference in patients' characteristics between the two groups, where sicker patients are more likely to receive femoral access and more stable patients receive transradial approach. Additionally, the registry did not include how many failed radial routes were converted to femoral procedures and did not account for bias related to operator experience and learning curves (34).

The Safety and Efficacy of Femoral Access versus Radial Access in STEMI (The SAFARI-STEMI Trial) is a recent multicentre randomized controlled trial performed in the United States. STEMI patients referred for primary PCI with symptom onset $<12$ hours were recruited and randomized to either transradial or transfemoral approach.

Major exclusion criteria were fibrinolytic therapy, oral anticoagulants and prior Coronary Artery Bypass Grafts (CABGs). The primary outcome investigated was all-cause mortality measured at 30 days. The trial also evaluated bleeding events and the composite of major adverse cardiac event (MACE) (35).

Transradial approach was performed in 1136 patients versus 1156 patients receiving transfemoral approach, with similar baseline characteristics and antithrombotic treatment in both groups. The study revealed no significant difference between the 30-day mortality rate in the transradial and transfemoral group (1.5\% vs $1.3 \%)$. The rate of secondary outcomes was similar for both groups and no major difference in bleeding rates (35).

The trial was stopped early by the Data Safety and Monitoring Board because it was highly unlikely that the trial would show a clinically important difference in 30-day all- cause mortality. The findings suggest that adequately trained operators should be able to achieve similar results using either radial or femoral access for primary PCI. The limitation of this study is that it is an underpowered trial and it is not clear whether similar good outcomes with femoral access seen in the trail can be achieved in clinical practice (35).

A systematic review of Transradial versus Transfemoral Approach for Diagnostic Angiography and Percutaneous Coronary Intervention in people with Coronary Artery Disease was performed examining the benefit versus harms of the transradial compared to the transfemoral approach in people with CAD undergoing PCI.

This review searched multiple databases including the Cochrane Central Register of Controlled Trials (CENTRAL) (36). After the application of exhaustive inclusion and exclusion criteria, 31 studies were identified which includes 27071 participants. 
Transradial access was associated with a reduction in net adverse clinical events, including death from cardiac cardiac causes, myocardial infarction, stroke, the need to reintervene on the same site of coronary artery stenosis, and bleeding during the first 30 days following intervention. While transradial access reduced death from cardiac causes, death from all causes during the first 30 days following intervention, bleeding, and local complications at the access site.

Further radial cases shortened the length of stay in hospital but was associated with a higher radiation exposure and more technical failures requiring an alternate vascular access route. Procedural success was less with the transradial approach, due to a higher rate of cross-over to a different arterial access. (36)

An important subgroup of patients are those with a previous history of CABGs. A retrospective cohort study by Amro et al revealed that in 216 out of 2153 patients who underwent transradial approach in patients with previous CABGs is had fewer complications and lower contrast use (37), with similar findings in a study done by Hirzallah (38). A safety and efficacy study of this group of patients undergoing TRA showed lower rate of bleeding and MACE compared to TFA (39). Of interest, a meta-analysis of transradial versus transfemoral PCI of left main disease also shown reduced lower bleeding risk while maintaining similar procedural success rate (40).Two studies compared the transradial and transfemoral approaches in people with cardiogenic shock. Both reported a reduction in mortality and MACE with the transradial approach.One study showed a reduction in access site-related and major bleeding (7753 participant)(41), while the other study (8131 participants) reported a reduction in short-term MACE (42).Gender disparity between the two approaches was examined in another study, showing transradial approch was safer and more efficacious in both genders with females having a higher cross-over rate to the femoral approach (43). Sirker et al addressed stroke as an outcome of interest in their meta-analysis and showed no differences between the two approaches (44).

Cost -effectiveness of radial vs femoral approach in primary percutaneous intervention in STEMI was assessed. A sub-analysis of the OCEAN RACE trial recruited 103 patients with myocardial infarction, and they were randomized to either radial or the femoral group. The procedures and length of hospital stay were meticulously logged, and costs were evaluated using the micro-cost method. The indirect costs, such as the patients' absence from work, were measured using the human capital approach (45).

This study revealed that clinical success was numerically higher in the radial group (90.4 vs $80.4 \%$ ) and there were no differences in MACE. The cost of therapeutic success was lower in theradial group at 3060 EUR versus 3374 EUR $(\mathrm{p}<0.01)$. The indirect costs were lower in the radial group compared to the femoral group. Although total in-hospital cost was similar between the study groups, the indirect cost is much lower in the radial group (45). Of interest, the increasing usage of transradial approach has spread to other disciplines. Transradial approach performed by radiologist for abdominal and peripheral intervention has shown less rate of complication but with longer procedural time compared to transfemoral approach (46). Comparison of transradial and transfemoral approach with thombectomy of anterior circulation stroke revealed equivalence in efficacy and efficiency (47).

Table 1: Summary of clinical studies assessing transradial and transfemoral approaches for cardiac catheterization

\begin{tabular}{|c|c|c|c|c|}
\hline $\begin{array}{l}\text { Author and the } \\
\text { year of } \\
\text { publication }\end{array}$ & Study Design & Sample size & Study objectives & Study findings \\
\hline Ahn et al 2019 (13) & $\begin{array}{l}\text { Retrospective } \\
\text { cohort study }\end{array}$ & $\begin{array}{l}22993 \text { patients in TRA } \\
\text { were compared to } 15581 \\
\text { patients in TFA }\end{array}$ & $\begin{array}{l}\text { To measure MACE and } \\
\text { complication rate in both } \\
\text { groups }\end{array}$ & $\begin{array}{l}\text { TRA group had lower rates } \\
\text { of death, MI and } \\
\text { transfusion rate }\end{array}$ \\
\hline $\begin{array}{l}\text { Amro et al } 2019 \\
(37)\end{array}$ & $\begin{array}{l}\text { Retrospective } \\
\text { cohort study }\end{array}$ & $\begin{array}{l}2153 \text { patients with } \\
\text { history of previous } \\
\text { CABGs undergoing PCI } \\
\text { with TFA and TRA }\end{array}$ & $\begin{array}{l}\text { To assess complication and } \\
\text { procedural issues in both } \\
\text { groups }\end{array}$ & $\begin{array}{l}\text { TRA in patients with } \\
\text { previous CABGs is } \\
\text { associated with lower rate } \\
\text { of complication }\end{array}$ \\
\hline $\begin{array}{l}\text { Brueck et al } 2009 \\
(30)\end{array}$ & $\begin{array}{l}\text { Randomized } \\
\text { controlled trial }\end{array}$ & $\begin{array}{l}1024 \text { patient undergoing } \\
\text { PCI assigned to TRA or } \\
\text { TFA (1:1) }\end{array}$ & $\begin{array}{l}\text { Evaluate the safety and } \\
\text { feasibility of TRA }\end{array}$ & $\begin{array}{l}\text { TRA is safe and effective. } \\
\text { However, procedural } \\
\text { duration and radiation } \\
\text { exposure are higher }\end{array}$ \\
\hline $\begin{array}{l}\text { Cantor at al } 2005 \\
(21)\end{array}$ & $\begin{array}{l}\text { Randomized } \\
\text { controlled trial }\end{array}$ & $\begin{array}{l}50 \text { patients with MI } \\
\text { randomized to TRA or } \\
\text { TFA }(1: 1)\end{array}$ & $\begin{array}{l}\text { To assess success rate of } \\
\text { PCI and procedure time } \\
\text { with TRA vs TFA }\end{array}$ & $\begin{array}{l}\text { PCI has high success rates } \\
\text { with both radial and } \\
\text { femoral access }\end{array}$ \\
\hline $\begin{array}{l}\text { Chase et al } 2008 \\
(20)\end{array}$ & $\begin{array}{l}\text { Retrospective } \\
\text { cohort study }\end{array}$ & $\begin{array}{llr}\text { From a } & \text { review } & \text { of } \\
\text { registry, } & 38 & 872 \\
\text { procedures } & & \text { were } \\
\text { analysed } & & \\
\end{array}$ & $\begin{array}{l}\text { To assess if TRA is } \\
\text { associated with reduction in } \\
\text { bleeding and transfusion. }\end{array}$ & $\begin{array}{l}\text { Transfusion patients had } \\
\text { increased 30-day mortality } \\
\text { (OR }-4.01) \text {. TRA halved } \\
\text { transfusion rates }\end{array}$ \\
\hline
\end{tabular}


Andrew AE., Azraai M.

\begin{tabular}{|c|c|c|c|c|}
\hline Dai et al 2018 (39) & $\begin{array}{l}\text { Retrospective } \\
\text { cohort study }\end{array}$ & $\begin{array}{l}184 \text { patients undergoing } \\
\text { TRA or TRA for PCI on } \\
\text { bypass grafts lesion }\end{array}$ & $\begin{array}{l}\text { To assess rate of } \\
\text { complication and MACE in } \\
\text { both groups }\end{array}$ & $\begin{array}{l}\text { TRA PCI for CABGs lesion } \\
\text { is associated with lower rate } \\
\text { of bleeding and in-hospital } \\
\text { MACE }\end{array}$ \\
\hline $\begin{array}{l}\text { De Carlo et al } 2009 \\
(25)\end{array}$ & $\begin{array}{l}\text { Prospective } \\
\text { cohort study }\end{array}$ & $\begin{array}{l}531 \text { patients undergoing } \\
\text { PCI with GPI treatment } \\
\text { were enrolled and } \\
\text { randomized to TRA and } \\
\text { TFA arm }\end{array}$ & $\begin{array}{l}\text { To assess rate of bleeding, } \\
\text { graded according to TIMI } \\
\text { classification }\end{array}$ & $\begin{array}{l}\text { TRA have significantly } \\
\text { lower rates of all types of } \\
\text { bleedings. }\end{array}$ \\
\hline $\begin{array}{l}\text { Dobies et al } 2016 \\
\text { (33) }\end{array}$ & $\begin{array}{l}\text { Retrospective } \\
\text { cohort study }\end{array}$ & $\begin{array}{lr}55 \quad 729 & \text { patients } \\
\text { undergoing } & \text { PCI } \\
\text { identified. 94.7\% } & \text { TFA } \\
\text { and 5.3\% TRA } & \\
\end{array}$ & $\begin{array}{l}\text { Comparison of TFA and } \\
\text { TRA in terms of safety and } \\
\text { efficacy }\end{array}$ & $\begin{array}{l}\text { TRA associated with longer } \\
\text { fluoroscopy times with less } \\
\text { major bleeding. }\end{array}$ \\
\hline $\begin{array}{l}\text { Fayaz et al } 2017 \\
(31)\end{array}$ & $\begin{array}{l}\text { Randomized } \\
\text { clinical trial }\end{array}$ & $\begin{array}{l}400 \text { patients admitted for } \\
\text { PCI were randomized to } \\
\text { TRA or TFA }(1: 1)\end{array}$ & $\begin{array}{l}\text { To assess ease } \begin{array}{r}\text { of } \\
\text { operability, time for } \\
\text { procedure, and failure rates }\end{array} \\
\text { in TRA vs TFA }\end{array}$ & $\begin{array}{l}\text { Fluoroscopy and overall } \\
\text { procedure time were longer } \\
\text { with TRA. However, } \\
\text { complication is more } \\
\text { frequent with TFA }\end{array}$ \\
\hline $\begin{array}{l}\text { Gandhi et al } 2015 \\
\text { (35) }\end{array}$ & $\begin{array}{l}\text { Systematic } \\
\text { review and } \\
\text { meta-analysis } \\
\end{array}$ & $\begin{array}{ll}6 \text { observational } & \text { studies, } \\
\text { with } 7753 & \text { patients } \\
\text { included } & \\
\end{array}$ & $\begin{array}{l}\text { Safety of TRA compared to } \\
\text { TFA approach in patients } \\
\text { with AMI and CS }\end{array}$ & $\begin{array}{l}\text { Lower adverse events in } \\
\text { TRA PCI group }\end{array}$ \\
\hline $\begin{array}{l}\text { Hirzallah et al } 2019 \\
(38)\end{array}$ & $\begin{array}{l}\text { Retrospective } \\
\text { cohort study }\end{array}$ & $\begin{array}{l}2153 \text { patients with } \\
\text { history of previous } \\
\text { CABGs undergoing PCI } \\
\text { with TFA and TRA }\end{array}$ & $\begin{array}{l}\text { To assess complication and } \\
\text { procedural issues in both } \\
\text { groups }\end{array}$ & $\begin{array}{l}\text { TRA in patients with } \\
\text { previous CABGs is } \\
\text { associated with lower rate } \\
\text { of complication }\end{array}$ \\
\hline $\begin{array}{l}\text { Huang et al } 2016 \\
\text { (37) }\end{array}$ & $\begin{array}{l}\text { Systematic } \\
\text { review and } \\
\text { meta-analysis }\end{array}$ & $\begin{array}{l}15 \text { studies, involving } 3 \\
921 \quad 848 \text { participants } \\
\text { were included }\end{array}$ & $\begin{array}{l}\text { To investigate gender } \\
\text { disparity in the safety and } \\
\text { efficacy of TRA and TFA }\end{array}$ & $\begin{array}{l}\text { TRA reduced risk of } \\
\text { bleeding in both sexes. } \\
\text { MACE reduced cross-over } \\
\text { rate increased in females. }\end{array}$ \\
\hline $\begin{array}{l}\text { Johnman et al } 2012 \\
\text { (22) }\end{array}$ & $\begin{array}{l}\text { Retrospective } \\
\text { cohort study }\end{array}$ & $\begin{array}{l}4534 \text { patients undergoing } \\
\text { PCI from April } 2000 \text { to } \\
\text { March } 2009\end{array}$ & $\begin{array}{l}\text { Assessment of procedural } \\
\text { success, peri-procedural } \\
\text { complications and MACE. }\end{array}$ & $\begin{array}{l}\text { TRA for PCI is associated } \\
\text { with improved clinical } \\
\text { outcomes }\end{array}$ \\
\hline Jolly SS 2011 (16) & $\begin{array}{l}\text { Randomized } \\
\text { clinical trial }\end{array}$ & $\begin{array}{l}7021 \text { patients with ACS } \\
\text { randomised to either } \\
\text { TRA or TFA }(1: 1)\end{array}$ & 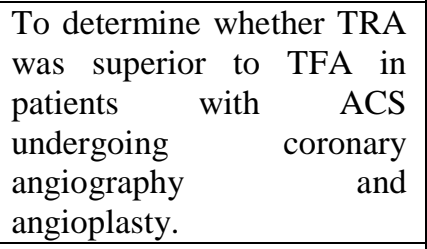 & $\begin{array}{l}\text { TRA is associated with } \\
\text { reduction in vascular } \\
\text { complications and reduction } \\
\text { in 30-day all-cause } \\
\text { mortality in STEMI } \\
\text { patients. }\end{array}$ \\
\hline $\begin{array}{l}\text { Kasasbeh et al } 2012 \\
\text { (31) }\end{array}$ & $\begin{array}{l}\text { Prospective } \\
\text { cohort study }\end{array}$ & $\begin{array}{l}1112 \text { diagnostic TRA } \\
\text { were divided into } 2 \\
\text { groups, performed by } \\
\text { high-volume or low- } \\
\text { volume operators. }\end{array}$ & $\begin{array}{l}\text { Assess reduction in } \\
\text { fluoroscopy and procedural } \\
\text { time over a 27-month } \\
\text { period }\end{array}$ & $\begin{array}{l}\text { Higher-volume operators } \\
\text { have reduced procedure and } \\
\text { fluoroscopy times. }\end{array}$ \\
\hline $\begin{array}{l}\text { Kolkailah et al } \\
2018(34)\end{array}$ & Meta-analysis & $\begin{array}{l}\text { RCTs comparing TRA } \\
\text { and TFA undergoing } \\
\text { PCI. } 31 \text { studies were } \\
\text { identified which includes } \\
\text { 27,071 participants }\end{array}$ & $\begin{array}{l}\text { Assess the benefits and } \\
\text { harm of TRA compared to } \\
\text { TFA }\end{array}$ & $\begin{array}{l}\text { TRA for PCI reduces short- } \\
\text { term MACE, cardiac death, } \\
\text { all cause mortality, bleeding } \\
\text { and } \\
\text { access site complications. }\end{array}$ \\
\hline $\begin{array}{l}\text { Koltowski et al } \\
2016(39)\end{array}$ & $\begin{array}{l}\text { Randomized } \\
\text { controlled trial }\end{array}$ & $\begin{array}{l}103 \text { patients with STEMI } \\
\text { were randomized to } \\
\text { either TRA or TFA }(1: 1)\end{array}$ & $\begin{array}{l}\text { To compare the cost } \\
\text { between TRA and TFA in } \\
\text { STEMI patients }\end{array}$ & $\begin{array}{l}\text { Indirect cost was lower in } \\
\text { the TRA group }\end{array}$ \\
\hline Looi et al 2011 (29) & $\begin{array}{l}\text { Prospective } \\
\text { cohort study }\end{array}$ & $\begin{array}{l}1001 \text { patient identified } \\
\text { (661 - TRA and } 340- \\
\text { TFA). Further analysis } \\
\text { performed according to } \\
\text { operators' } \\
\text { experience (RExs vs } \\
\text { nRExs) with } 12 \text { months } \\
\text { follow up }\end{array}$ & $\begin{array}{l}\text { Comparison of TRA to TFA } \\
\text { coronary angiography } \\
\text { procedural times and } \\
\text { learning curve of TRA }\end{array}$ & $\begin{array}{l}\text { In the TRA group, nRExs } \\
\text { had longer fluoroscopic and } \\
\text { procedural times compared } \\
\text { to RExs. However, both } \\
\text { were equivalent in the final } \\
3 \text { months of analysis. }\end{array}$ \\
\hline
\end{tabular}


Andrew AE., Azraai M.

\begin{tabular}{|c|c|c|c|c|}
\hline $\begin{array}{l}\text { Mann et al } 2000 \\
(24)\end{array}$ & $\begin{array}{l}\text { Prospective } \\
\text { cohort study }\end{array}$ & $\begin{array}{l}218 \text { patients underwent } \\
\text { PCI (1:1, TRA: TFA) }\end{array}$ & $\begin{array}{l}\text { Measurement of multiple } \\
\text { outcomes including cost } \\
\text { and time to ambulation }\end{array}$ & $\begin{array}{l}\begin{array}{l}\text { TRA resulted in better } \\
\text { outcomes, } \\
\text { ambulation and lower cost. }\end{array} \\
\text { ambrer }\end{array}$ \\
\hline $\begin{array}{l}\text { Mehta et al } 2012 \\
(17)\end{array}$ & $\begin{array}{l}\text { Subgroup } \\
\text { analysis of } \\
\text { RIVAL (16) }\end{array}$ & $\begin{array}{l}\text { Randomized to TRA vs } \\
\text { TFA }\end{array}$ & $\begin{array}{l}\text { To compare outcomes in } \\
\text { both groups, such as MACE } \\
\text { and vascular access site } \\
\text { complication. }\end{array}$ & $\begin{array}{l}\text { Reduction of major } \\
\text { vascular complications with } \\
\text { TRA especially in women } \\
(3.1 \text { vs } 6.1 \% \text { p }<0.0001) \text {. } \\
\text { PCI success rate was } \\
\text { similar in both genders. }\end{array}$ \\
\hline $\begin{array}{l}\text { Michel Le May } \\
2019(34)\end{array}$ & $\begin{array}{l}\text { Multicentre } \\
\text { randomized } \\
\text { controlled trial }\end{array}$ & $\begin{array}{l}\text { Patients with STEMI } \\
\text { with symptoms onset } \\
\text { less than } 12 \text { hours for } \\
\text { PCI. } 1136 \text { patients in } \\
\text { TRA and } 1156 \text { patients } \\
\text { in TFA group }\end{array}$ & $\begin{array}{l}\text { Primary outcome is } 30 \text {-day } \\
\text { mortality rate and } \\
\text { secondary outcome is } \\
\text { MACE event and bleeding } \\
\text { rate }\end{array}$ & 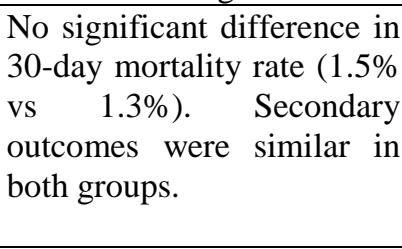 \\
\hline $\begin{array}{l}\text { Mitchell et al } 2012 \\
(28)\end{array}$ & $\begin{array}{l}\text { Systematic } \\
\text { review and } \\
\text { meta-analysis }\end{array}$ & $\begin{array}{l}14 \text { studies were } \\
\text { identified }\end{array}$ & $\begin{array}{l}\text { A cost-benefit analysis of } \\
\text { radial catheterization }\end{array}$ & TRA favoured over TFA \\
\hline $\begin{array}{l}\text { Pancholy et al } 2015 \\
\text { (32) }\end{array}$ & $\begin{array}{l}\text { Randomized } \\
\text { controlled trial }\end{array}$ & $\begin{array}{l}1493 \text { patients undergoing } \\
\text { CA randomized in } 1: 1 \\
\text { ratio to TRA or TFA }\end{array}$ & $\begin{array}{l}\text { Comparison of radiation } \\
\text { exposure time between } \\
\text { TRA and TFA }\end{array}$ & $\begin{array}{l}\text { Radiation exposure was } \\
\text { similar during diagnostic } \\
\text { CA with TRA and TFA }\end{array}$ \\
\hline $\begin{array}{l}\text { Pancholy et al } 2015 \\
(36)\end{array}$ & $\begin{array}{l}\text { Systematic } \\
\text { review }\end{array}$ & $\begin{array}{l}8 \text { studies, involving } 8131 \\
\text { patients with } \mathrm{CS} \\
\text { undergoing PCI }\end{array}$ & $\begin{array}{l}\text { Determine the benefit of } \\
\text { TRA in patient with CS } \\
\text { undergoing PCI }\end{array}$ & $\begin{array}{lcr}\text { TRA associated } & \text { with } \\
\text { reduced mortality } & \text { and } \\
\text { MACE at } 30 \text { days } & \end{array}$ \\
\hline $\begin{array}{l}\text { Romagnoli et al } \\
2012(23)\end{array}$ & $\begin{array}{l}\text { Randomized } \\
\text { control trial }\end{array}$ & $\begin{array}{l}\text { 1001 STEMI patients } \\
\text { undergoing PCI. } 500 \\
\text { patients randomized to } \\
\text { TRA and 501 to TFA }\end{array}$ & $\begin{array}{l}\text { To assess if TRA for } \\
\text { STEACS is associated with } \\
\text { better outcome compared to } \\
\text { TFA }\end{array}$ & $\begin{array}{l}\text { 30-day MACE is lower in } \\
\text { the TRA arm }(13.6 \%) \\
\text { compared to TFA arm } \\
(21.0 \%)\end{array}$ \\
\hline $\begin{array}{l}\text { Saito et al } 2003 \\
(19)\end{array}$ & $\begin{array}{l}\text { Randomized } \\
\text { control trial }\end{array}$ & $\begin{array}{l}149 \text { patients with AMI } \\
\text { randomized to TRA and } \\
\text { TFA }(1: 1)\end{array}$ & $\begin{array}{l}\text { Comparing MACE between } \\
\text { the two approaches }\end{array}$ & $\begin{array}{l}\text { Success rate of reperfusion } \\
\text { and MACE similar in both } \\
\text { groups (TRA - } 96.1 \text { and } \\
5.2 \% \text { vs TFA }-97.1 \% \text { and } \\
8.3 \% \text { ) }\end{array}$ \\
\hline $\begin{array}{l}\text { Sinhal et al } 2016 \\
(23)\end{array}$ & $\begin{array}{l}\text { Randomized } \\
\text { controlled trial }\end{array}$ & $\begin{array}{l}2014 \text { patients with ACS } \\
\text { undergoing PCI were } \\
\text { randomized to TRA and } \\
\text { TFA }\end{array}$ & $\begin{array}{l}\text { To compare rate of MACE } \\
\text { in both groups }\end{array}$ & $\begin{array}{l}\text { TRA associated with a } \\
\text { lower incidence of MACE }\end{array}$ \\
\hline $\begin{array}{l}\text { Sirker et al } 2016 \\
(38)\end{array}$ & $\begin{array}{l}\text { Systematic } \\
\text { review and } \\
\text { meta- analysis }\end{array}$ & $\begin{array}{l}\text { Pooled data from } \\
>24000 \text { patients in RCT } \\
\text { and >475000 patients } \\
\text { from observational } \\
\text { studies used }\end{array}$ & $\begin{array}{l}\text { To evaluate stroke } \\
\text { complicating PCI through } \\
\text { TRA versus TFA }\end{array}$ & $\begin{array}{l}\text { TRA is not associated with } \\
\text { increased risk of stroke } \\
\text { events }\end{array}$ \\
\hline $\begin{array}{l}\text { Valgimigli et al } \\
2015(18)\end{array}$ & $\begin{array}{l}\text { Randomized } \\
\text { clinical trial }\end{array}$ & $\begin{array}{l}8404 \text { participants with } \\
\text { ACS undergoing PCI. } \\
\text { Participants allocated to } \\
\text { either TRA or TFA }(1: 1)\end{array}$ & $\begin{array}{l}\text { To compare TRA versus } \\
\text { TFA approach in terms of } \\
\text { MACE and episodes of } \\
\text { major bleeding }\end{array}$ & $\begin{array}{l}\text { TRA associated with } \\
\text { reduced vascular-access } \\
\text { complications, MACE, } \\
\text { all-cause mortality and } \\
\text { major bleeding rates. }\end{array}$ \\
\hline
\end{tabular}

TRA - Transradial approach, TFA - Transfemoral approach, PCI -Percutaneous coronary intervention, GPI Glycoprotein inhibitor, TIMI - Thrombolysis in Myocardial Infarction Score, AMI - Acute myocardial infarction, CS Cardiogenic shock, MACE - Major adverse cardiac event, CABGs - Coronary Artery Bypass Graft, RExs - Radial expert, NRExs - Non-radial expert.

\section{Conclusion}

The transradial approach for PCI reduces access site complications, time to ambulation and reduces cardiac related death and morbidity in acute coronary syndrome populations. Whether this approach is applicable across all interventions including elective cases remains uncertain. The major impediment of such approach is the lack of training and hesitancy of older interventionalists to switch approaches.
While the transfemoral approach has a higher access site complication rate, it is still integral as an access option. The possibility that radial approach (compared to femoral) may have a higher long-term rate of periprocedural stroke requires vigilant surveillance.

Conflict of Interest: None. 


\section{References}

1. Levine GN, et al. 2015 ACC/AHA/SCAI focused update on primary percutaneous coronary intervention for patients with ST-elevation myocardial infarction: an update of the 2011 ACCF/AHA/SCAI guideline for percutaneous coronary intervention and the 2013 ACCF/AHA guideline for the management of STelevation myocardial infarction: A report of the American College of Cardiology/American Heart Association Task Force on Clinical Practice Guidelines and the Society for Cardiovascular Angiography and Interventions. Catheter Cardiovasc Interv. 2016; 87(6):1001-1019.

2. Amsterdam EA, et al. 2014 AHA/ACC guideline for the management of patients with non-ST-elevation acute coronary syndromes: a report of the American College of Cardiology/American Heart Association Task Force on Practice Guidelines. J Am Coll Cardiol. 2014;64(24):e139-e228.

3. Moscucci M. Grossman \& Baim's cardiac catheterization, angiography, and intervention: Lippincott Williams \& Wilkins; 2013.

4. Nasser TK, Mohler III ER, Wilensky RL, Hathaway DR. Peripheral vascular coronary inte-rventional procedures. Clin Cardiol. 1995;18(11):609-614.

5. Applegate RJ, et al. Trends in vascular complications after diagnostic cardiac catheterization and percutaneous coronary intervention via the femoral artery, 1998 to 2007. JACC Cardiovasc Interv. 2008;1(3):317-326.

6. Sesana M, et al. Effectiveness and complications of vascular access closure devices after interventional procedures. J Invasive Cardiol. 2000;12(8):395-399.

7. Dauerman HL, Rao SV, Resnic FS, Applegate RJ. Bleeding avoidance strategies: consensus and controversy. J Am Coll Cardiol. 2011;58(1):1-10.

8. Marso SP, et al. Association between use of bleeding avoidance strategies and risk of periprocedural bleeding among patients undergoing percutaneous coronary intervention. JAMA. 2010;303(21):2156-2164.

9. Kiemeneij F, Laarman GJ, Odekerken D, Slagboom T, van der Wieken R. A randomized comparison of percutaneous transluminal coronary angioplasty by the radial, brachial and femoral approaches: the access study. J Am Coll Cardiol. 1997;29(6):1269-1275.

10. Mann T, et al. Stenting in acute coronary syndromes: a comparison of radial versus femoral access sites. J Am Coll Cardiol. 1998;32(3):572-576.

11. Jolly SS, Amlani S, Hamon M, Yusuf S, Mehta SR. Radial versus femoral access for coronary angiography or intervention and the impact on major bleeding and ischemic events: a systematic review and meta-analysis of randomized trials. Am Heart J. 2009;157(1):132-140.

12. Feldman DN, et al. Adoption of radial access and comparison of outcomes to femoral access in percutaneous coronary intervention: an updated report from the national cardiovascular data registry (2007-2012).Circulation. 2013;127:2295-2306.

13. Ahn SG, et al. In-hospital outcome differences between transradial and transfemoral coronary approaches: Data from the Korean percutaneous coronary intervention registry. Catheter Cardiovasc Interv. 2019;1-7.

14. Bertrand OF, et al. Transradial approach for coronary angiography and interventions: results of the first international transradial practice survey. JACC Cardiovasc Interv. 2010;3(10):1022-1031.

15. Mamas MA, et al. Minimising radial injury: prevention is better than cure. EuroIntervention. 2014;10(7):824-832.

16. Mehta SR, et al. Effects of radial versus femoral artery access in patients with acute coronary syndromes with or without ST-segment elevation. J Am Coll Cardiol. 2012;60(24):2490-249.

17. Jolly SS, et al. Radial versus femoral access for coronary angiography and intervention in patients with acute coronary syndromes (RIVAL): a randomised, parallel group, multi-centre trial. Lancet. 2011;377(9775):1409-1420.

18. Valgimigli M, et al. Radial versus femoral access in patients with acute coronary syndromes undergoing invasive management: a randomised multicentre trial. Lancet. 2015;385(9986):2465-2476.

19. Chase AJ, et al. Association of the arterial access site at angioplasty with transfusion and mortality: the M.O.R.T.A.L study (Mortality benefit Of Reduced Transfusion after percutaneous coronary intervention via the Arm or Leg). Heart. 2008;94(8):1019-1025.

20. Cantor WJ, et al. Radial versus femoral access for emergent percutaneous coronary intervention with adjunct glycoprotein IIb/IIIa inhibition in acute myocardial infarction - the RADIAL-AMI pilot randomized trial. Am Heart J. 2005;150(3):543549.

21. Johnman $\mathrm{C}$, et al. Clinical outcomes following radial versus femoral artery access in primary or rescue percutaneous coronary intervention in Scotland: retrospective cohort study of 4534 patients. Heart. 2012;98(7):552-557.

22. Romagnoli E, et al. Radial versus femoral randomized investigation in ST-segment elevation acute coronary syndrome: the RIFLE-STEACS (Radial Versus Femoral Randomized Investigation in ST-Elevation Acute Coronary Syndrome) study. Acute J Am Coll Cardiol. 2012;60(24):2481-2489.

23. Sinhal N, Allada C, Rahman M, O'Connor S, Farshid A. Outcome of Transradial Versus Transfemoral Intervention in Acute Coronary Syndromes. Heart, Lung and Circulation. 2016;25:S185. 
24. Mann T, et al. Transradial coronary stenting: comparison with femoral access closed with an arterial suture device. Catheter Cardiovasc Interv. 2000;49(2):150-156.

25. De Carlo M, et al. Effectiveness of the transradial approach to reduce bleedings in patients undergoing urgent coronary angioplasty with GPIIb/IIIa inhibitors for acute coronary syndromes. Catheter Cardiovasc Interv. 2009;74(3):408-415.

26. Bertrand OF, et al. A randomized study comparing same-day home discharge and abciximab bolus only to overnight hospitalization and abciximab bolus and infusion after transradial coronary stent implantation. Circulation. 2006;114(24):2636-2643.

27. Jabara $\mathrm{R}$, et al. Ambulatory discharge after transradial coronary intervention: Preliminary US single-center experience (Same-day TransRadial Intervention and Discharge Evaluation, the STRIDE Study). Am Heart J. 2008;156(6):1141-1146.

28. Mitchell MD, Hong JA, Lee BY, Umscheid CA, Bartsch SM, Don CW. Systematic review and cost-benefit analysis of radial artery access for coronary angiography and intervention. Circ Cardiovasc Qual Outcomes. 2012;5(4):454-462.

29. Looi JL, Cave A, El-Jack S. Learning curve in transradial coronary angiography. Am J Cardiol. 2011;108(8):1092-1095.

30. Brueck M, Bandorski D, Kramer W, Wieczorek M, Holtgen R, Tillmanns H. A randomized comparison of transradial versus transfemoral approach for coronary angiography and angioplasty. JACC Cardiovasc Interv. 2009;2(11):1047-1054.

31. Bhat FA, Changal KH, Raina H, Tramboo NA, Rather HA. Transradial versus transfemoral approach for coronary angiography and angioplasty - A prospective, randomized comparison. BMC Cardiovasc Disord. 2017; 17:23.

32. Kasasbeh ES, et al. Learning curve in transradial cardiac catheterization: procedure-related parameters stratified by operators' transradial volume. J Invasive Cardiol. 2012;24(11):599-604.

33. Pancholy SB, Joshi P, Shah S, Rao SV, Bertrand OF, Patel TM. Effect of Vascular Access Site Choice on Radiation Exposure During Coronary Angiography: The REVERE Trial (Randomized Evaluation of

Vascular Entry Site and Radiation Exposure). JACC Cardiovasc Interv. 2015;8(9):1189-1196.

34. Dobies DR, Barber KR, Cohoon AL. Analysis of safety outcomes for radial versus femoral access for percutaneous coronary intervention from a large clinical registry. Open Heart. 2016;3(2):e000397.

35. MR. LM. The Safety and Efficacy of Femoral Access vs Radial Access in STEMI: The SAFARI-STEMI Trial. ACC;2019.

36. Kolkailah AA, et al. Transradial versus transfemoral approach for diagnostic coronary angiography and perc- -utaneous coronary intervention in people with coronary artery disease. Cochrane Database Syst Rev. 2018;4:Cd012318.

37. Amro A, et al. 100.45 Transradial Versus Transfemoral Access for Coronary Angiography and Intervention in Patients With Previous History of Coronary Artery Bypass Surgery. JACC: Cardiovascular Interventions. 2019;12(4 Supplement):S14.

38. Hirzallah $\mathrm{H}$, et al. Comparison of transradial and transfemoral approaches for coronary angiography and percutaneous intervention in patients with coronary bypass grafts. Cardiovasc Revasc Med. 2019; pii: S1553-8389(19)30164-2.

39. Dai Y, et al. Safety and Efficacy of Percutaneous Coronary Intervention via Transradial Versus Transfemoral Approach in Bypass Grafts. Angiology. 2018; 69(2):136-142.

40. Ando $\mathrm{T}$, et al. Transradial versus transfemoral percutaneous coronary intervention of left main disease: A systematic review and meta-analysis of observational studies. Catheter Cardiovasc Interv. 2018;1-10.

41. Gandhi S, Kakar R, Overgaard CB. Comparison of radial to femoral PCI in acute myocardial infarction and cardiogenic shock: a systematic review. J Thromb Thrombolysis. 2015;40(1):108-117.

42. Pancholy SB, et al. Impact of access site choice on outcomes of patients with cardiogenic shock undergoing percutaneous coronary intervention: A systematic review and meta-analysis. Am Heart J. 2015;170(2):353-361.

43. Huang FY, et al. Gender Disparity in the Safety and Efficacy of Radial and Femoral Access for Coronary Intervention: A Systematic Review and Meta-Analysis. Angiology. 2016;67(9):810-819.

44. Sirker A, et al. Influence of access site choice for cardiac catheterization on risk of adverse neurological events: A systematic review and metaanalysis. Am Heart J. 2016;181:107-119.

45. Koltowski L, et al. Cost-effectiveness of radial vs. femoral approach in primary percutaneous coronary intervention in STEMI -Randomized, control trial. Hellenic J Cardiol. 2016;57(3):198-202.

46. Hung ML, Lee EW, McWilliams JP, Padia SA, Ding P, Kee ST. A reality check in transradial access: a single-centre comparison of transradial and transfemoral access for abdominal and peripheral intervention. Eur Radiol. 2019;29(1):6874.

47. Chen Stephanie H, et al. Abstract WP35: A Comparison of Transradial versus Transfemoral Access in Anterior Circulation Mechanical Thrombectomy. Stroke.50 (Suppl_1) : AWP35. 